\title{
The History behind the Discovery of Root Tension Signs and the Invention of the Lumbar Discectomy Surgery
}

\author{
Kshitij Chaudhary ${ }^{1,2}$
}

Sciatica, a common affliction, has been a well-known scourge throughout recorded history of mankind and finds a mention in the writings of Hippocrates [1]. The clinical root tension signs were described in the late 19th century, and their discovery preceded the development of surgical techniques for this disorder. As surgeries became safe at the beginning of the 20th century, surgeons incorrectly diagnosed the pathology as cartilaginous tumors in these operated patients. Finally, by the 1930s, they had started connecting the dots and discovered that lumbar disc herniation was responsible for the clinical syndrome of sciatica. In this report, we trace an interesting history from the discovery of the root tension signs for sciatica to the invention of lumbar discectomy surgery for a herniated lumbar disc.

There is a great deal of confusion in the eponymous naming of the passive Straight-Leg Raise (SLR) test in various textbooks. Bruce Reider's The Orthopaedic Physical Examination, a book popular among orthopedic residents, describes the forced dorsiflexion maneuver as the Laségue's test [2], while Todd Albert's Physical Examination of the Spine describes the same maneuver as Bragard's test [3]. Most textbooks, however, refrain from using eponymous names to describe these neurological signs, especially because there is so much confusion about them. Nevertheless, the medical history behind these root tension signs is no less fascinating.

Many attribute the first description of the passive SLR to Ernst Charlie Laségue (Fig. 1), who was a Professor of Medicine in Paris. In his 1864 paper, he described a syndrome of radicular pain which sometimes was associated with muscle atrophy [4]. However, in this paper, he did not describe the leg raising test. Robert Wartenberg, the owner of a few eponymous signs and syndromes himself, wrote in 1956: "It is highly embarrassing to state the plain fact that all authors who quoted Lasègue's article of 1864 as a source of Lasègue's sign did not read the article" [5].

\begin{tabular}{|c|c|c|}
\hline Access this article online & Author's Photo Gallery & $\begin{array}{l}\text { 'Department of Orthopaedics, Consultant Spine Surgeon, PD Hinduja hospital and Medical Research Center, Mumbai. Maharashtra. India. } \\
{ }^{2} \text { Department of Orthopaedics, T. N. Medical College \& BYL Nair Ch. Hospital, Mumbai. Maharashtra. India. }\end{array}$ \\
\hline $\begin{array}{c}\text { Website: } \\
\text { www.jocr.co.in }\end{array}$ & & Address of Correspondence: \\
\hline $\begin{array}{c}\text { DOI: } \\
10.13107 / \text { jocr.2021.v11.i01.1992 }\end{array}$ & & $\begin{array}{l}\text { Dr. Kshitij Chaudhary, } \\
\text { PD Hinduja hospital and Medical Research Center, Veer Savarkar Marg, Mahim. Mumbai } 400 \text { 016. Maharashtra. India. }\end{array}$ \\
\hline & Dr. Kshitij Chaudhary & E-mail: drkshitijchaudhary@gmail.com \\
\hline
\end{tabular}

Journal of Orthopaedic Case Reports | pISSN 2250-0685 | eISSN 2321-3817 | Available on www.jocr.co.in | doi:10.13107/jocr.2021.v11.i01.1992

This is an Open Access article distributed under the terms of the Creative Commons Attribution Non-Commercial License (http://creativecommons.org/licenses/by-nc/3.0) which permits unrestricted non-commercial use, distribution, and reproduction in any medium, provided the original work is properly cited.
Ironically, he himself had misquoted Laségue's paper as the source of the sign in his publication a decade earlier [6].

The SLR test was actually first published as a doctoral thesis in 1881 by Laségue's 30-year-old student Jean Joseph Forst [7]. Forst acknowledged that his teacher was the discoverer of this phenomenon and dedicated his thesis to Laségue (pronounced Lasaeg) in addition to his parents. Note that, Forst described two components of the test. The first was the leg raising test with knee extension and the second component was the relief of pain on knee flexion (the verification maneuver or the control test). Most descriptions of the original Laségue's test forget to mention the second part of the test. Peculiarly, for some unknown reasons, the original diagram in Forst's thesis shows that the second part of the test is being done on a different man (Fig. 2). This man is clean-shaven and his neck is in greater flexion compared to the bearded man in the first picture.

However, both Lasegue and Forst got the explanation for the sign wrong. They thought that it was due to the pressure of the hamstrings muscles on the sciatic nerve rather than the stretch of the nerve itself. Three years later, in 1884, another Frenchman, Beurmann, disproved Forst's thesis using a cadaver model [8]. He concluded, correctly, that by lifting the leg the sciatic nerve gets stretched and the muscles play no role in compressing it.

As usual, the twist in the tale is that another physician came up with this test independently of Laségue and Forst. Lazar K. Lazarević (Fig. 3a), the personal physician of the Serbian King, published a description of this test in a Serbian language medical journal in 1880, a year before Forst's thesis [9]. Besides, unlike Laségue and Forst, he correctly attributed the phenomenon to the stretching of the sciatic nerve. He even measured the distance from his own posterior superior iliac spine to the heel and found that in the supine position it measured $103 \mathrm{~cm}$ and at maximum SLR position it was $111 \mathrm{~cm}$. 


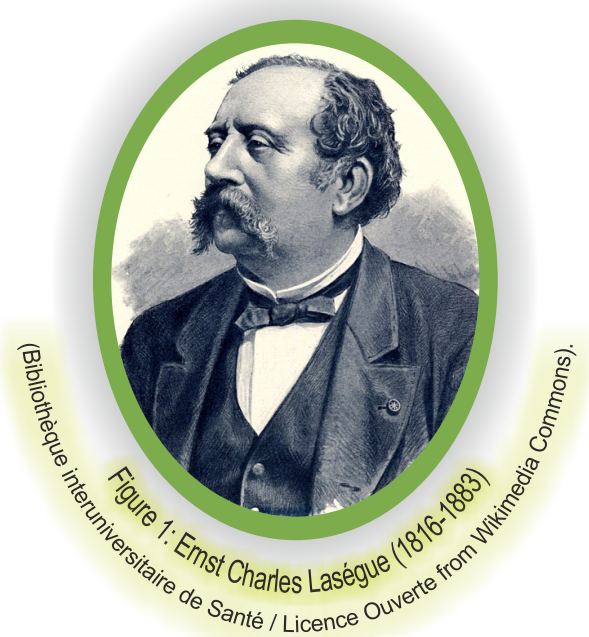

He concluded that this $8 \mathrm{~cm}$ increase was responsible for the stretch of the sciatic nerve [10]. He later translated it in German and published it in 1884.

Lazarević may have the claim of priority, but Laségue's name stuck and became popular. This was not surprising considering that Laségue was famous as the head of the Trousseau clinic in Paris and was the pupil of the famous neurologist Armand Trousseau (known for another famous eponymous sign, the Trousseau sign of latent tetany) [11]. Moreover, publishing in the Serbian language probably did not help Lazarević's cause. Some authors, however, have tried to resurrect his memory and claim that this test should be called the Lazarevićs sign [12, 13].
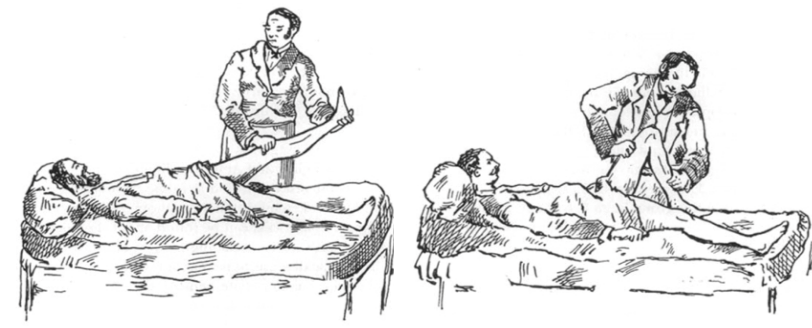

Figure 2: Original illustration from Forst's thesis depicting the Laségue's test in two parts

Modifications of the passive SLR were later described. The crossed SLR or the well-leg SLR test was first described by a Polish neurologist Izydor Fajersztajn-Krzemicki in 1901 (Fig. 4a) [14]. He conducted cadaver dissections to show that the traction on the sciatic nerve on the one side pulled the dural sac caudally and ipsilaterally which, in turn, stretched the contralateral roots along with it (Fig. 4B and C). Hence, the well-leg SLR or the crossed SLR is eponymously known as Fajersztajn sign. We tried to look up the correct pronunciation of the Polish name "Fajersztajn" but were unsuccessful. Hence, we would recommend students describe this test as the well-leg or crossed SLR instead of incorrectly pronouncing a proper name.

In the same paper, Fajersztajn also described that the pain during the Laségue's test was worsened by forced dorsiflexion of the ankle. However, for some unknown reason, this maneuver is usually attributed to a German, Karl Bragard (1890-1973) who published it much later in 1928 [15]. There is another earlier description, in 1913, of this maneuver by a fellow German, Maurice Roch who called it the "Laségue of the foot" [16]. Bragard does not deserve the eponym, but maybe he gave a better explanation for this phenomenon in his paper and made this test popular. He proposed this maneuver as a qualifying test for the Lasegue's test as the latter was too frequently positive (overtly sensitive). The two reasons given by Bragard for a Pseudolaségue sign (false positive Laségue's) were "Muskelhaerten" (muscle hardness in German and what we now call hamstring tightness) and malingering patients. The Bragard test was an attempt to improve the specificity of the Laségue's test.

Classically, in the original description by both Fajersztajn and Bragard, the test is performed by forced dorsiflexion at the point of the start of pain. It is considered positive when the pain is exacerbated. Today, we usually practice a modification of this test. The leg is lowered slightly until the pain is relieved and forced dorsiflexion reproduces the pain. The first mention of this modification to the Bragard's test appears in a 1942 letter by Mester [17]. He also described a reversed Bragard sign in which a sudden extension of the foot at the start of pain during a passive SLR gives relief from pain [17].

Interestingly, these tests were described before the scientific community had made the connection between lumbar disc herniation and sciatica. By 1890, the world had accepted Joseph Lister's principles of antisepsis and surgeries had become safer.

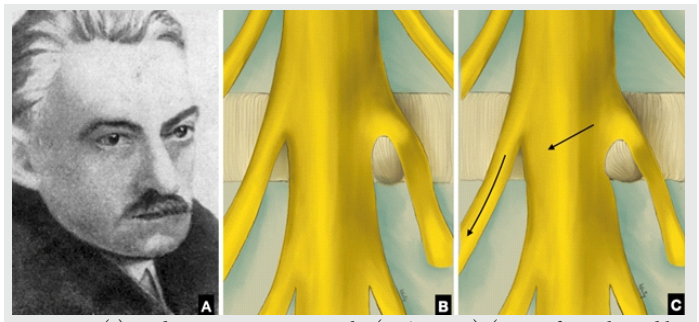

Figure 4: (a) Izydor Fajersztajn-Krzemicki (1867-1935) (Image from the public domain) Graphical sketch for the explanation of the well-leg SLR (b) showing the affected root stretched over a herniated disc in the axillary position. (c) Raising the wellleg causes the root to pull on the dural sac moving it ipsilaterally and caudally, stretching the contralateral nerve root over the herniated fragment.
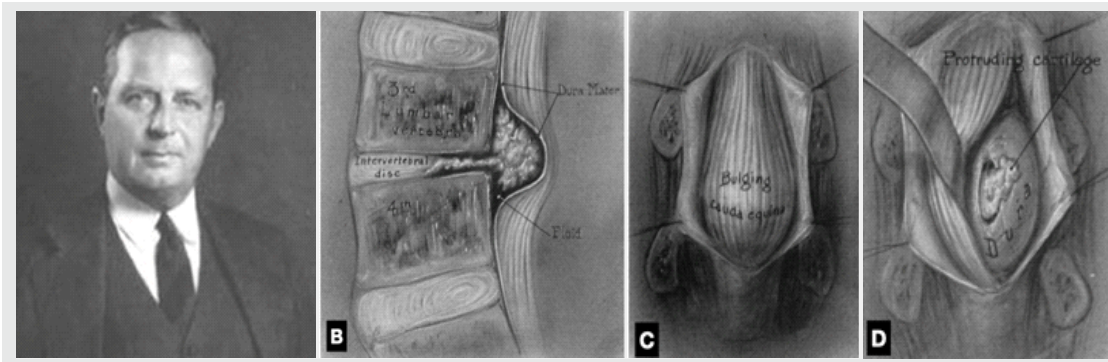

Figure 5: (a) Walter E. Dandy (1886-1946) (Image from public domain) (b) Graphical sketch showing ruptured intervertebral disc herniating into spinal canal (candd) transdural removal of the disc fragment. (b, $c$, and d from Dandy's original 1929 publication [21]) 


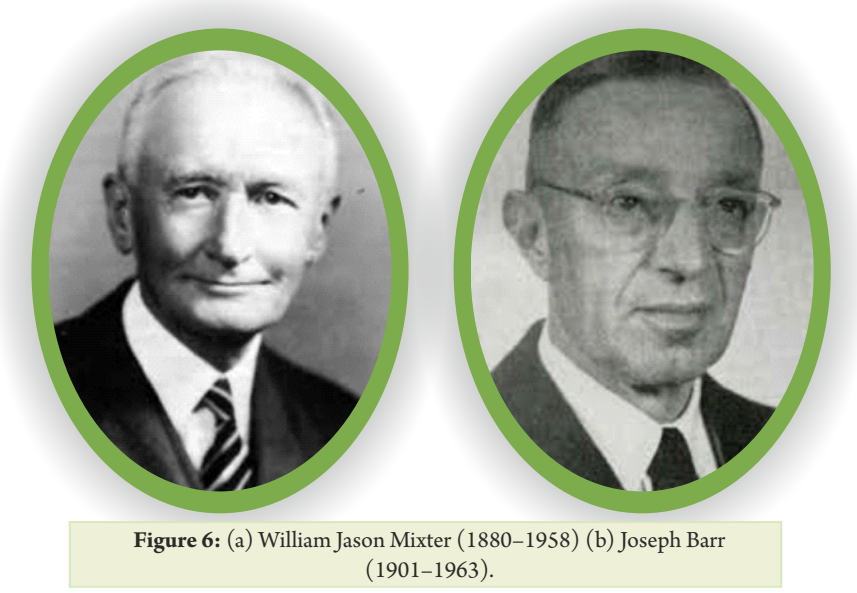

The first surgery for lumbar disc herniation was done in Berlin in 1908 by the neurosurgeon Fred Krause following the advice of the neurologist Hermann Oppenheim. The lesion was resected transdurally and was misdiagnosed as enchondroma [18]. In retrospect, several such surgeries during the 1920s and mid-1930s reported as enchondromas or chondromas of the lumbar spine were probably intervertebral discherniations. The only imaging study available was Lipidol myelography which was introduced by Sicard and Forestier in 1928 [19]. Hence, it was understandable why surgeons were pronouncing cartilagenous tissue found in the spinal canal as tumors.

However, some astute surgeons were already having doubts about the true nature of sciatica. In 1911, Joel Goldthwait, the Chairman of Orthopaedic Surgery at the Massachusetts General Hospital (MGH), Boston encountered a patient with sciatica and progressive neurological deficit. He referred the patient to Harvey Cushing who had recently been appointed as the Surgeon-in-Chief at Peter Bent Brigham Hospital. Cushing did the laminectomy but no intraspinal pathology was found. Goldthwait was the first to speculate that a ruptured disc could be the cause of the patient's symptoms. He hypothesized "such a condition could produce symptoms of sciatica and low back pain" and speculated that it must have "slipped back into place" and hence was not found during surgery [20].

In 1929, Walter Dandy (Fig. 5a) from Johns Hopkins Hospital, Baltimore, reported two cases of cauda equina syndrome that he had operated and removed loose cartilaginous fragments transdurally (Fig. 5b, c and d). He correctly identified them as disc herniations and thought them to be "undoubtedly traumatic" in etiology $[21,22]$. This report preceded the famous Mixter and Barr publication by 5 years.

Back again in Boston, in 1932, Joseph Barr (Fig. 6b), an orthopedic surgeon was treating a 25-year-old man for the left leg pain following a skiing accident. The patient did not improve with conservative therapy and hence he referred the patient to William Jason Mixter (Fig. 6a), a neurosurgeon at MGH Boston who for many was "the man in New England who knew the most about the spine" (Harvey Cushing, the father of neurosurgery, who had operated Goldthwait's patient two decades ago, was more famous for his intracranial work) [23]. On June 29, 1932, Mixter operated the patient and removed a mass pressing the S1 nerve root through a L2-S1 laminectomy and labeled it an "enchondroma" in accordance with the zeitgeist of that era. Although the histology matched that of a normal disc, Charles S. Kubick, the pathologist at MGH called it a tumor because the mass was found in the spinal canal. A few days later, Mixter had a serendipitous meeting with Barr in the corridors of $\mathrm{MGH}$ where they discussed their mutual patient. Barr disagreed with the diagnosis of "enchondroma" and told Mixter that it did not make chronological sense as the patient clearly reported an acute onset of leg pain following a traumatic event. The kind Dr. Mixter, instead of dismissing Barr, allowed him and Kubick to review all his previously operated patients with the diagnosis of "spinal enchondroma." Kubick confirmed that the histology of these cases also matched that of normal discs. By this time, Christian Georg Schmorl (1861-1932), a pioneering German pathologist had published his voluminous and authoritative work on pathology of disc after studying 10000 cadaver spines $[24,25]$. He not only described the prolapse of the disc into the vertebral body (known eponymously as a Schmorl's node) but also discovered posterior prolapses behind the posterior longitudinal ligament. He proposed that this was due to weakening of the annulus fibrosis due to degenerative changes. However, he did not give this finding clinical importance and in fact suggested that because they were so commonly identified in autopsy specimens they must be asymptomatic in real life [24]. It was Mixter and Barr who correlated Schmorl's findings with their clinical experience and concluded that these disc herniations were responsible for sciatica and the Lasegue's sign. Six months later, on December 19, 1932, Mixter performed the first lumbar discectomy with a pre-operative diagnosis of "lumbar disc herniation." After considerable resistance and scepticism from the medical community, their case series of 19 patients was immortalized in the now famous 1934 NEJM publication "Rupture of the intervertebral disc with involvement of the spinal canal" (Figure 7) [26]. Note that the approach to the lumbar disc so far was transdural until 1938 when J. Grafton Love (Figure 8a), Chief of Neurosurgery at Mayo Clinic, published an extradural approach (Figure $8 \mathrm{~b}$ ) which was the precursor of the modern open lumbar discectomy [27]. Many surgeons, including Walter Dandy, visited Mayo Clinic to perfect Love's technique of interlaminar discectomy.

Although Mixter and Barr acknowledged Dandy in their publication, Walter Dandy, tried to claim precedence and his dissatisfaction is discernible in a letter he wrote to a colleague: "If you will read my article on ruptured intervertebral disc in the 


\title{
NEW ENGLAND SURGICAL SOCIETY
}

\section{RUPTURE OF THE INTERVERTEBRAL DISC WITH INVOLVEMENT OF THE SPINAL CANAL•}

\author{
BY WILIUM JASON MIXTER, M.D., $\dagger$ AND JOSEPH S. BARR, M.D. $\dagger$
}

D URING the last few years there has been a good deal written and a large amount of clinical work done stimulated by Schmorl's ${ }^{1}$ investigation of the condition of the intervertebral dise as found at autopsy. His work will stand

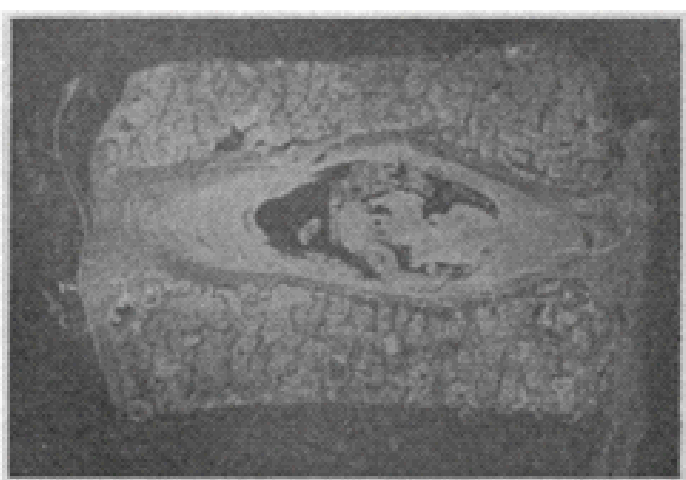

FIG. 1. A normal intervertebral disc. Note cartilage plate. anterior and posterlor longitudinal ligament, annulus sbroses, and the semifluid nucleus pulposus which bears the superincum. bent body welght and is retained in place under preasure by the annulus.
In 1911 Goldthwait ${ }^{2}$ reported a case of sciatica and paraplegia which he attributed to a posterior displacement of the intervertebral dise at the lumbosacral junction and suggested that such displacements might be the cause of many

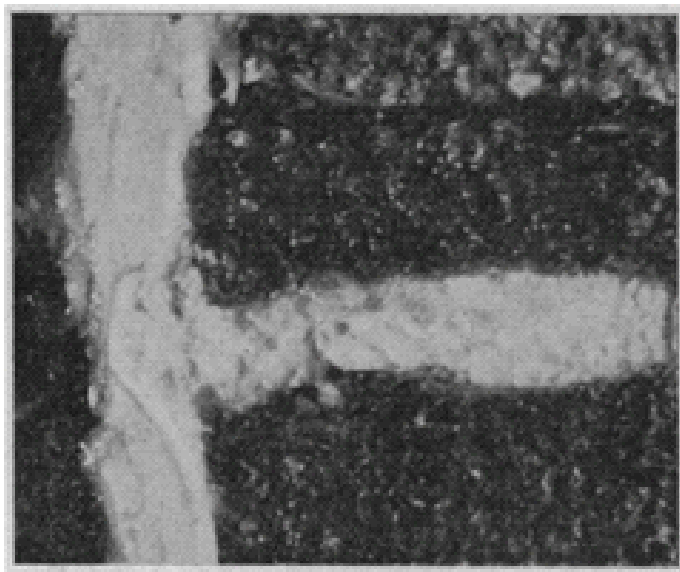

FIG. 2. Autopsy specimen. CASE 5. Note mall posterlor prolapse wuch as Schmorl describes.

\section{A}

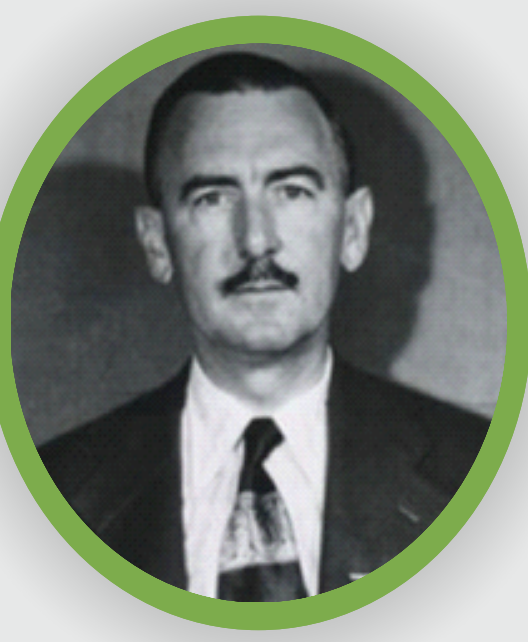

B

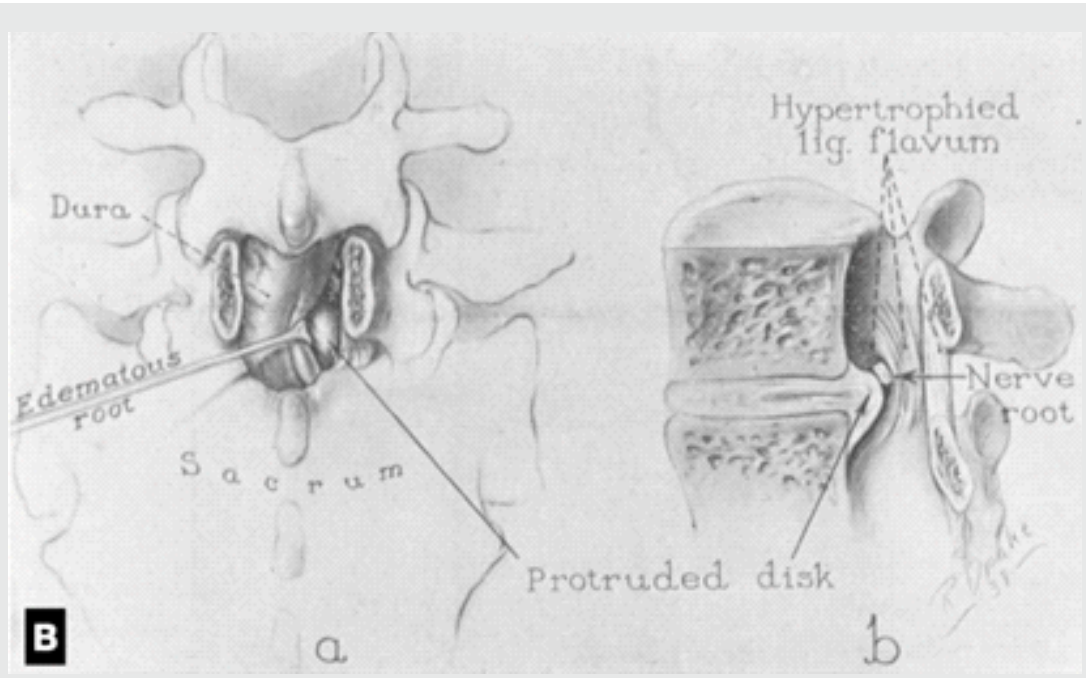

Figure 8: (a) J Grafton Love (1903-1987) (b) Interlaminar "key hole" extradural approach for lumbar microdiscectomy (from Love JG. Protruded Intervertebral Disc (Fibrocartilage): (Section of Orthopædics and Section of Neurology). Proceedings of the Royal Society of Medicine. 1939;32:1697-721) 
Archives of Surgery, 1929, you will find that this was the beginning of the attack on this lesion, Mixter came very much later and added nothing except the recognition of the lesion with a partial block" [23] Ultimately, Dandy's report did not garner much attention because it was a case report consisting of only two cases of cauda equina syndrome (complete block on myelogram), a much rarer condition than the common unilateral radicular pain syndrome (partial block). Mixter and Barr's report went "viral" and provoked tremendous enthusiasm among surgeons to solve all lumbar disc problems with or without leg pain with surgery. Therefore, Mixter and Barr's can be credited with ushering in, as Macnab described, the "dynasty of the disc." It was not until the 1980s investigators recognized the favorable natural history of acute lumbar radicular pain that the pendulum swung back to conservative care.

\section{References}

1. Karampelas I, Boev AN, Fountas KN, Robinson JS. Sciatica: A historical perspective on early views of a distinct medical syndrome. Neurosurg Focus 2004; 16:1-4.

2. Reider B. The Orthopaedic Physical Examination. United States: Elsevier Saunders; 2005.p. 424.

3. Albert TJ, Vaccaro AR. Physical Examination of the Spine. United States: Thieme; 2016.p. 204.

4. Lasegue E. Consideration su la sciatique. Arch Gen Med 1864;6:558-80.

5. Wartenberg R. On neurologic terminology, eponyms and the lasègue sign. Neurology 1956;6:853.

6. Wartenberg R. Stretching test in neuritis. Calif West Med 1941;55:76-9.

7. Forst JJ. Comtribution al'etude clinique de la sciatique. These $\mathrm{P}$ a ris ; 1881 . Available from : https://www.ci.nii.ac.jp/naid/10017561881. [Last accessed on 2020 May 20].

8. De Beurmann L. Note sur un signe peu connu de la sciatique: Recherches experimentales. Arch Physiol Norm Pathol 1884;16:375-80.

9. Lazarevic LK. Ischias postica contunnii-jedan prilog za njenu diferencijalnu Dijagnozu. Srp Arch Celok Lek 1880;7:2335.

10. Karbowski K, Radanov BP. The history of the discovery of the sciatica stretching phenomenon. Spine 1995;20:13157.

11. Hall GW. Neurologic signs and their discoverers. J Am Med Assoc 1930;95:703.

12. Drača S, Lazar K. Lazarević, the author who first described the straight leg raising test. Neurology 2015;85:1074.

13. Maranhão-Filho P, Vincent $M$, Maranhão-Filho $P$, Vincent M. Lazarević-Lasègue sign. Arq Neuropsiquiatr 2018;76:421-3.

14. Fajersztajn J. Über das gekreuzte Ischiasphänomen. Wien
Klin Wochenschr 1901;14:41-7.

15. Bragard K. Ueber das laseguesche phanomen. Munch Med Wochenschr 1928;75:387-9.

16. Koehler PJ, Bruyn GW, Pearce JM. Neurological Eponyms. 1st ed. Oxford: Oxford University Press; 2000.p. 386.

17. Mester AJ. New diagnostic sign in sciatica. BMJ 1942;2:2466.

18. Oppenheim H, Krause F. Ueber einklemmung bzw. Strangulation der cauda equina. Dtsch Med Wochenschr 1909;35:697-700.

19. Truumees E. A history of lumbar disc herniation from Hippocrates to the 1990s. Clin Orthop 2015;473:1885-95.

20. Goldthwait JE. The lumbo-sacral articulation; An explanation of many cases of lumbago sciatica and paraplegia. Boston Med Surg J 1911;164:365-72.

21. Dandy WE. Loose cartilage from intervertebral disc simulating tumor of the spinal cord. Arch Surg 1929; 19:660-72.

22. Weinstein JS, Burchiel KJ. Dandy's disc. Neurosurgery 2009;65:201.

23. Parisien RC, Ball PA. Historical perspective William Jason mixter (1880-1958). Spine 1998;23:2363-6.

24. Schmorl G, Junghanns H. Archiv Und Atlas Der Normalen Und Pathologischen Anatomie in Typischen Röntgenbildern. United States: Leipsig Georg Thieme; 1932.

25. Vernon-Roberts B. Historical perspective Christian Georg schmorl. Spine 1994;19:2724-7.

26. Mixter WJ, Barr JS. Rupture of the intervertebral disc with involvement of the spinal canal. N Engl J Med 1934;211:210-5.

27. Love JG, Walsh MN. Protruded intervertebral disks: Report of one hundred cases in which operation was performed.J Am Med Assoc 1938;111:396-400. 
How to Cite this Article

Chaudhary K. The History behind the Discovery of Root Tension Signs and the Invention of the Lumbar Discectomy Surger. Journal of Orthopaedic Case Reports 2021 January; 11(1): 121-126 